\title{
Herbage Yield and Quality of Threadleaf Sedge
}

\section{J. STUBBENDIECK AND MICHAEL A. FOSTER}

\begin{abstract}
Highlight: An investigation of herbage yield, crude protein, and in vitro dry matter disappearance (IVDMD) levels of ungrazed threadleaf sedge (Carex filifolia Nutt.) was conducted over a 2-year period in western Nebraska. Threadleaf sedge contributed approximately $80 \%$ of the total herbage production on the study site. Crude protein varied from over $18 \%$ in late April to $5 \%$ or less in February. Levels of IVDMD varied from $69 \%$ in May to $51 \%$ in March. Levels of these quality factors were higher than those for most grasses throughout the year.
\end{abstract}

Threadleaf sedge (Carex filifolia Nutt.) is one of the most important grass-like range plants in the grasslands of the Great Plains (Weaver and Albertson 1956; Coupland 1961). Threadleaf sedge occurs on dry plains and hills from Manitoba to British Columbia, south to Texas, and as far west as California (Fernald 1950; Britton and Brown 1970). This species is commonly found growing in association with needleandthread (Stipa comata Trin. \& Rupr.) and blue gama (Bouteloua gracilis (H.B.K.) Lag. ex Steud.), but can thrive on dry ridges and in places where little other vegetation can survive (Weaver and Albertson 1956).

Threadleaf sedge is a long-lived perennial which forms a tough sod. Threadleaf sedge is densely tufted with pale green glabrous culms and may reach a height of 8 to $36 \mathrm{~cm}$. The leaves of threadleaf sedge are filiform and may be from 5 to $25 \mathrm{~cm}$ long and approximately $0.6 \mathrm{~cm}$ wide (Britton and Brown 1970).

Threadleaf sedge resumes growth in early spring and completes growth in late May. This plant is especially valuable for grazing during this period, because it maintains high palatability for all classes of livestock. By the end of June it becomes dry and tough. The low growth form of threadleaf sedge and the resistance of its tough, wiry roots enables it to withstand heavy grazing and trampling. Its roots are brown or black in color and form a tangled mat to a depth of $0.5 \mathrm{~m}$, with some roots reaching a depth of $1.5 \mathrm{~m}$ (Weaver and Albertson 1956).

Although ranchers in the shortgrass prairie pay a premium for rangeland containing threadleaf sedge, little information is available on its herbage yield or quality. Research on other species of Carex in Canada has shown herbage yields ranging from 380 to $6,400 \mathrm{~kg} /$ hectare and an average crude protein percentage of 9.1 (Gorham and Sommers 1973; van Ryswyk et al. 1973). Goetz (1975) has shown that the crude protein percentage of threadleaf sedge growing in North Dakota compared favorably to that of blue grama, varying from $12.8 \%$ on May 15 to $6.4 \%$ on August 15. He stated that the high loss of "leaf material" greatly reduced the value of this species for summer grazing.

Authors are associate professor of agronomy (range management), University of Nebraska, Lincoln 68583; and research associate, Texas A\&M University, Research and Extension Center, Vernon, Texas 76384.

I his report is a contribution of the Nebraska Agricultural Experiment Station as Technical Paper Number 5450.

Manuscript received October 24, 1977.
Our objectives were to determine (1) herbage yield and (2) herbage quality, measured as percentage crude protein and in vitro dry matter disappearance (IVDMD), of threadleaf sedge.

\section{Study Area}

The study site was located in western Nebraska, approximately 16 $\mathrm{km}$ south of Scottsbluff. Average annual precipitation at the study site is $366 \mathrm{~mm}$, although precipitation levels during the 2-year study were below average at 328 and $269 \mathrm{~mm}$ for 1975 and 1976, respectively.

The soil at the study site was classified as Mitchell silt loam (Ustic Torriorthent), with a 3 to 5\% slope. This soil is a deep, well-drained soil with a medium textured layer beneath a brownish gray surface layer (Yost et al. 1968). The study area was fenced to exclude domestic livestock and was classified as a silty range site. Threadleaf sedge occupied $79 \%$ of the basal herbage area of the study site, and plants growing in association with it included blue grama, needleandthread, and sand dropseed (Sporobolus cryptandrus Torr.).

\section{Methods}

A harvesting schedule was initiated on January 4, 1975, and completed on December 6, 1976. Twenty-four harvests were made during each year. Harvest frequency varied from weekly, during active growth periods, to monthly, during periods of dormancy. Four quadrats $\left(2.3 \mathrm{~m}^{2}\right)$ were clipped near the soil surface in each of four replications in a randomized complete block design. A series of plots was used, enabling the use of previously unharvested plots. All aboveground biomass was removed by clipping on March 10 of each year. Threadleaf sedge herbage was separated from other herbage, weighed, and dried in a forced air oven at $65^{\circ} \mathrm{C}$ until reaching a constant weight and weighed. Samples were ground to 40-mesh size and saved for nitrogen and IVDMD analyses. Percentage crude protein was determined by the Kjeldahl procedure (Assoc. Official Agr. Chem. 1960). The method outlined by Tilley and Terry (1963) was used for the IVDMD determinations.

\section{Herbage Yield}

\section{Results and Discussion}

Herbagc yicld decreased from the January sampling date through the early April sampling date both years (Fig. 1). This was due to winter loss of plant materials. Growth resumed in early April of both years, as indicated by an increase in moisture levels of the herbage.

Maximum herbage yield of $883 \mathrm{~kg} /$ hectare was recorded on June 27 in 1975, 1 weck later than in 1976 (Fig. 1). Weaver and Albertson (1956) reported that threadleaf sedge in South Dakota completed growth approximately 1 month earlier than that reported here. Above-average precipitation $(158 \mathrm{~mm})$ was recorded from late May through June 1975, thus enabling the plants to reach a higher production level than in 1976.

Moisture levels of the herbage reached a maximum of only $64 \%$ in 1975 and $68 \%$ in 1976 , considerably less than maximums generally recorded for other forage species (Table 1). Loss of plant material due to breakage of dry tissue from the ungrazed threadleaf sedge began in the spring. Regrowth occurred during September 1975, following closely the receipt of $53 \mathrm{~mm}$ of rainfall. Following a relatively dry period (May through 


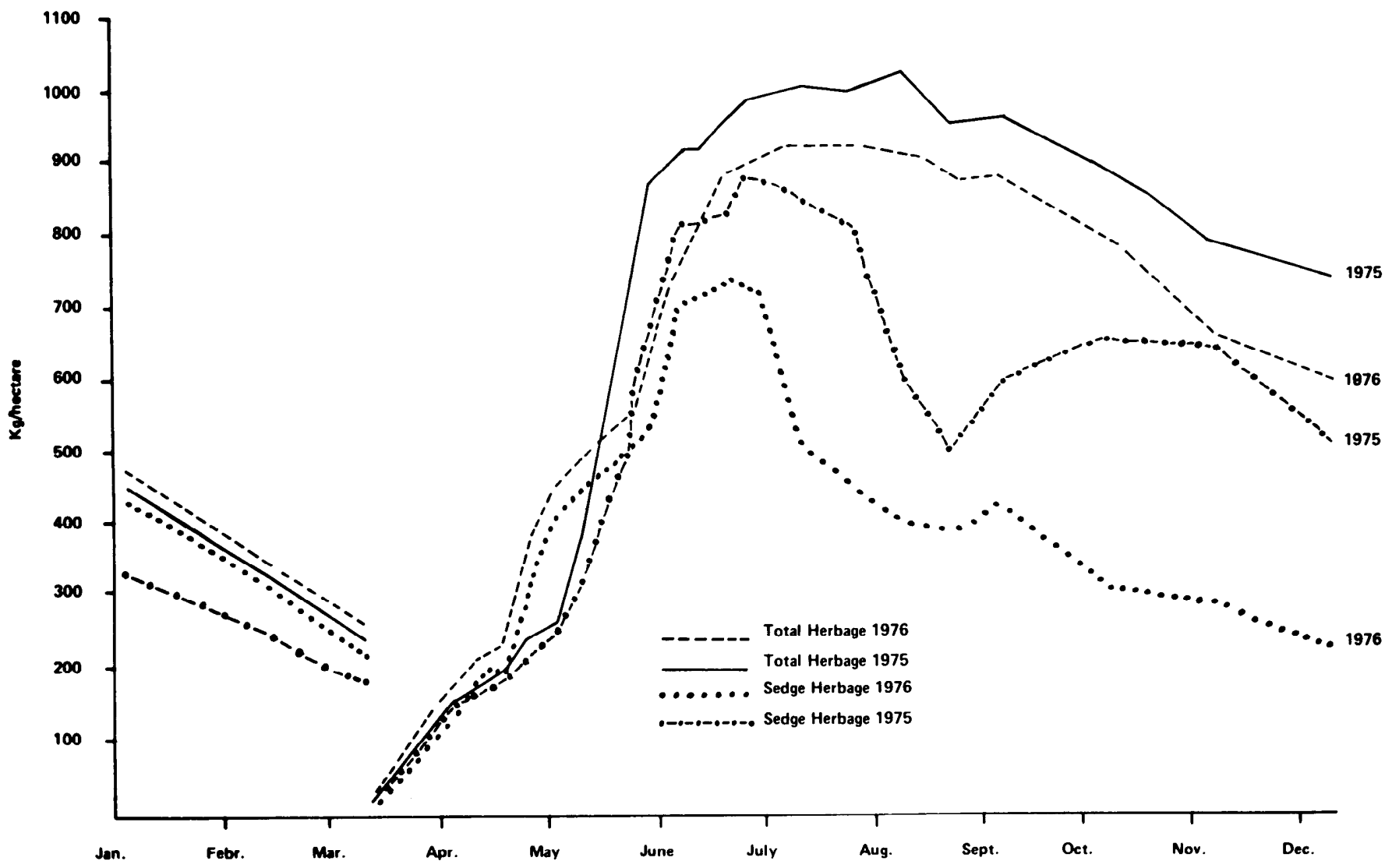

Fig. 1. Total and sedge herbage yields during 1975 and 1976.

July), only a small amount of regrowth occurred in September 1976.

Threadleaf sedge contributed a major portion of the herbage production on the study site (Fig. 1). Herbage yield of threadleaf sedge reached a maximum of 883 and $740 \mathrm{~kg} /$ hectare in 1975 and 1976, respectively. Total herbage yield reached 1,030 $\mathrm{kg} / \mathrm{hectare}$ in 1975 and $925 \mathrm{~kg} /$ hectare in 1976.

Percentage crude protein was lowest during the late fall through early spring when averages ranged from 5 to $6 \%$ (Table 1). This crude protein range compares favorably with that reported for blue grama and is somewhat higher than that of other mature grasses (Williams 1953; Rogers and Box 1967; Nat. Acad. Sci. 1976). Burzlaff (1971) found that crude protein levels of little bluestem (Schizachyrium scoparium (Michx.) Nash.), prairie sandreed (Calamolvifa (Hook.) Scribn.), and sand blucstem (Andropogon hallii Hack.) grown at Fort Robinson in western Nebraska were 2\%, or less, on November 1 . This $2 \%$ level can be compared to the crude protein content of threadleaf sedge, which was approximately $6 \%$ on November 1 .

Crude protein increased rapidly with resumption of spring growth (Table 1). Maximum crude protein was recorded in late April both years. Crude protein levels for the mid May sampling date were approximately 2.5 percentage units higher than those reported for threadleaf scdge during the same period in North Dakota (Goetz 1975). Crude protein declined from mid May until early July. Crude protein levels in late July were approximately $7 \%$. Burzlaff (1971) reported crude protein levels of the three warm-season range grasses to be from 1 to 3 percentage units lower than threadleaf sedge during the same time period. Perry (1974) detcrmined the crude protein levels of sand bluestem and prairie sandreed grown on the Panhandle Experimental
Range, near Scottsbluff. He found that the crude protein content was $5.5 \%$ for prairie sandreed in late July. A slight increase in crude protein content of threadleaf sedge occurred in conjunction with the regrowth during September 1975.

Table 1. Moisture content (\%), crude protein (\%), and IVDMD (\%) of threadleaf sedge over a 2-year period at Scottsbluff, Nebr.

\begin{tabular}{|c|c|c|c|c|c|c|}
\hline \multirow{2}{*}{$\begin{array}{l}\text { Harvest date } \\
1975 / 1976 \\
\end{array}$} & \multicolumn{2}{|c|}{ Moisture content } & \multicolumn{2}{|c|}{ Crude protein } & \multicolumn{2}{|c|}{ IVDMD } \\
\hline & 1975 & 1976 & 1975 & 1976 & 1975 & 1976 \\
\hline Jan. $4 / 5$ & 9 & 9 & 6.1 & 5.7 & 56 & 56 \\
\hline Feb. 4/5 & 9 & 9 & 5.8 & 4.7 & 55 & 55 \\
\hline March 4/5 & 9 & 9 & 6.2 & 6.2 & 51 & 51 \\
\hline April $4 / 5$ & 28 & 28 & 6.8 & 6.8 & 57 & 57 \\
\hline April $11 / 12$ & 38 & 57 & 10.6 & 10.6 & 62 & 63 \\
\hline April $18 / 19$ & 50 & 62 & 16.4 & 16.1 & 67 & 65 \\
\hline April $25 / 26$ & 55 & 68 & 18.0 & 18.6 & 67 & 67 \\
\hline May $2 / 3$ & 60 & 67 & 17.7 & 17.9 & 69 & 68 \\
\hline May $9 / 10$ & 62 & 66 & 16.5 & 16.6 & 67 & 69 \\
\hline May $16 / 17$ & 64 & 65 & 15.3 & 15.5 & 66 & 66 \\
\hline May $23 / 24$ & 60 & 62 & 14.8 & 14.4 & 65 & 67 \\
\hline May $30 / 31$ & 60 & 62 & 13.6 & 13.5 & 64 & 63 \\
\hline June $6 / 7$ & 60 & 60 & 12.4 & 11.8 & 63 & 61 \\
\hline June $13 / 14$ & 54 & 57 & 11.0 & 11.0 & 62 & 62 \\
\hline June $20 / 21$ & 48 & 54 & 9.7 & 9.3 & 62 & 61 \\
\hline June $27 / 28$ & 36 & 52 & 8.4 & 8.3 & 62 & 62 \\
\hline July $11 / 12$ & 38 & 45 & 7.9 & 7.5 & 61 & 59 \\
\hline July $25 / 26$ & 38 & 40 & 7.0 & 7.4 & 59 & 56 \\
\hline Aug. 8/9 & 30 & 23 & 7.0 & 7.1 & 58 & 56 \\
\hline Aug. $22 / 23$ & 24 & 14 & 7.0 & 6.7 & 57 & 56 \\
\hline Sept. $5 / 6$ & 32 & 14 & 7.7 & 6.5 & 58 & 56 \\
\hline Oct. $5 / 6$ & 23 & 12 & 6.2 & 6.5 & 55 & 56 \\
\hline Nov. $5 / 6$ & 9 & 11 & 6.0 & 6.1 & 56 & 56 \\
\hline Dec. $5 / 6$ & 9 & 10 & 5.9 & 5.7 & 56 & 56 \\
\hline LSD. & \multicolumn{2}{|c|}{2} & \multicolumn{2}{|c|}{0.5} & \multicolumn{2}{|c|}{2} \\
\hline
\end{tabular}


Cows nursing calves (average milking ability during the first 3 to 4 months postpartum) require a total protein level of $9.2 \%$ (Nat. Acad. Sci. 1976). Threadleaf sedge met these requirements from resumption of spring growth until approximately June 20 (Table 1). Dry pregnant mature cows require 5.9\% total protein in their diets (Nat. Acad. Sci. 1976). Threadleaf sedge essentially met these requirements throughout the year, with the possible exception of the months of December, January, and February. In addition, grazing animals are selective and generally consume forage of higher nutritive value than harvested total herbage.

\section{In Vitro Dry Matter Disappearance}

In vitro dry matter disappearance (IVDMD) values were lowest in March $(51 \%)$ before resumption of spring growth (Table 1). This was considerably higher than IVDMD values for most dry, mature grasses (Streeter et al. 1968; Nat. Acad. Sci. 1976). Burzlaff (1971) found IVDMD levels on November 1 to be $38 \%$ for prairie sandreed, $37 \%$ for little bluestem, and $46 \%$ for sand bluestem. These values can be compared to the approximate 56\% IVDMD of threadleaf sedge in early November. Percentage IVDMD increased rapidly during April and May. Percentages of IVDMD of more than $60 \%$ are not uncommon for immature range grasses, but these values rapidly decline in the summer (Burzlaff 1971; Perry 1974). Percentage IVDMD did not drop below $60 \%$ until July and remained above $55 \%$ until February.

\section{Literature Cited}

Association of Official Agricultural Chemists. 1960. Official Methods of Analysis (9th Ed.). Ass. Official Chem., Washington, D.C. 832 p.

Britton, N. L., and A. Brown. 1970. An illustrated Flora of the Northern United States and Canada. Vol. 1. Dover Publ., Inc., New York. 680 p.

Burzlaff, D. F. 1971. Seasonal variations of the in vitro dry matter digestibility of three sandhill grasses. J. Range Manage. 24:60-63.

Coupland, R. T. 1961. A reconsideration of grassland classification in the northern Great Plains of North America. J. Fcol. 49:135-167.

Fernald, M. L. 1950. Gray's Manual of Botany. (8th Ed.). Amer. Book Co., New York. 1632 p.

Goetz, H. 1975. Effect of site and fertilization on protein content of native grasses. J. Range Manage. 38:380-385.

Gorham, E., and M. G. Sommers. 1973. Seasonal changes in the standing crop of two montane sedges. Canadian J. Bot. 51:1097-1108.

National Academy of Sciences. 1976. Nutrient requirements of domestic animals. No. 4. Nutrient Requirements of Beef Cattle. Nat. Acad. Sci., Washington, D.C. 56 p.

Perry, L. J., Jr. 1974. Two big grasses of the Sandhills. Quarerly. Univ. of Nebraska. Inst. Agr. and Natur. Resour. 21:5-6.

Rogers, J. D., and T. W. Box. 1967. Seasonal protein content for four southern mixed prairie grasses. J. Range Manage. 20:177-178.

Streeter, C. L., D. C. Clanton, and O. E. Hoehne. 1968. Influence of advance of season on nutritive value of forage consumed by cattle grazing western Nebraska native range. Univ. of Nebraska, Lincoln. Res. Bull. 277. $21 \mathrm{p}$.

Tilley, J. M. A., and R. A. Terry. 1963. A two-step technique for the in vitro digestion of forage crops. J. British Grassl. Soc. 18:104-111.

Van Ryswyk, A. L., W. A. Hubbard, and J. E. Miltmore. 1973. Beef production potential and chemical composition of fertilized and unfertilized sedge hay grown on organic soil of interior British Columbia. Canadian J. Anim. Sci. 55:181-186.

Weaver, J. E., and F. W. Albertson. 1956. Grasslands of the Great Plains. Johnson Publ. Co., Lincoln, Nebraska. 395 p

Williams, J. S. 1953. Seasonal trends of minerals and proteins in prairie grasses. J. Range Managge. 6:100-108.

Yost, D. A., D. L. Brown, L. L. Buller, and J. O. Olson. 1968. Soil survey of Scotts Bluff County, Nebraska. U.S. Dep. Agr., Washington, D.C. 110 p.
Effects of Poisonous Plants on Livestock

Edited by RICHARD F. KEELER, KENT R. VAN KAMPEN and LYNN F. JAMES

The papers presented provide an up-to-date, welldocumented examination of the principal poisonous plants of the United States and Australia, with some treatment of plants from England, Canada, and New Zealand. Research in the United States and Australia on the effects of poisonous plants on livestock is in the vanguard, and the authors represented are among the leading scientists working in the area of poisonous plants.

SECTION HEADINGS: Introductory Remarks. General Topics. Simple Phytotoxins. Plant Hepatotoxins. Plant Cardio/Pulmonary Toxins. Plant Neurotoxins. Plant Tcratogens and Toxins Affecting Reproduction. Other Toxicities.

1978, 640 pp., $\$ 29.50 / £ 19.15$ ISBN: 0-12-403250-8

\section{Plant Geography}

\section{WITH SPECIAL REFERENCE TO NORTH AMERICA}

BY REXFORD DAUBENMIRE

\section{A Volume in the PHYSIOLOGICAL ECOLOGY Series}

Plant Geography gives perhaps the most complete account to date of the natural vegetation of North America and how it developed through time. The book, ideal as a text for courses in plant geography, interprets as well as describing. The author uses an ecosystem perspective to view climate, soil, and fire in relation to vegetation, and also considers economic values and land uses. He makes full use of palcoecology to intepret how the vegetation distribution arose that was here when the white man arrived.

1978, 352 pp., $\$ 21.50 / £ 15.25$ ISBN: 0-12-204150-X

Now Available from Academic Press . . .

\section{Nitrogen in Desert Ecosystems}

Edited by NEIL E. WEST and JOHN SKUJINS

Volume 9 in the US/IBP Synthesis Series

As compared to other ecosystems, the scientific research on nutrient cycling in arid lands has been negligible until this decade. This volume presents an initial report on progress toward improving our understanding of the role of one chemical element in the structure, function, and control of desert ecosystems. In 17 chapters, the contributors review the previous state of knowledge on the nitrogen cycle in these contexts and add their own new expansion of data and conclusions. The result is a comprehensive overview of the topic.

1978, 304 pp., \$18.00/£11.70 iSBN: 0-12-787752-5

Published by Dowden, Hutchinson \& Ross, Inc. Distributed exclusively and worldwide by Academic Press, Inc. For complete information on the US/IBP Synthesis Series, please write to Academic Press.

Send payment with order and save postage plus $50 \notin$ handling charge. Prices are subject to change without notice.

U.S. customers please note: On prepaid orders-payment will be refunded for titles on which shipment is not possible within 120 days.

\section{ACADEMIC PRESS, INC.}

A Subsidiary of Harcourt Brace Jovanovich, Publishers

111 FIFTH AVENUE, NEW YORK, N.Y. 10003

24-28 OVAL ROAD, LONDON NW1 7DX

Please send me the following:

-copies, Keeler et al:: Effects of Poisonous Plants on Livestock

copies, Daubenmire: Plant Geography

copies, West/Skujins: Nitrogen in Desert Ecosystems

(US/IPB Synthesis Series V. 9/DH\&R)

Check enclosed Bill me__

NAME

ADDRESS.

CITY/STATE/ZIP

New York residents please add sales tax.

Direct all orders to Mr. Paul Negri, Media Dept

JRangeMgmt/7/78 